\title{
Activity, distribution and regulation of phosphofructokinase in salivary gland of rats with streptozotocin-induced diabetes
}

\section{Atividade, distribuição e regulação da fosfofrutoquinase em glândulas salivares de ratos com diabetes induzido por estreptozotocina}

\author{
José Nicolau* \\ Douglas Nesadal Souza** \\ Fernando Neves Nogueira*
}

\begin{abstract}
Although the influence of diabetes on salivary glands is well studied, it still presents conflicting results. In this work, the regulation of the phosphofructokinase-1 enzyme (PFK-1) was studied utilizing the salivary glands of rats. Diabetes was induced by a single intraperitoneal injection of streptozotocin $(60 \mathrm{mg} / \mathrm{Kg}$ of body weight) in rats (180-200 g). The animals were killed 30 days after the induction of diabetes and the submandibular and parotid salivary glands were used. Hyperglycemia was evaluated by blood sugar determination. The distribution of PFK-1 between the soluble and cytoskeleton fractions, the phosphate content of PFK-1, the content of fructose-2,6-bisphosphate and the activity of the PFK-2 enzyme were determined. The calculated relative glandular weight showed a higher value for the parotid gland in comparison with the control, but not for the submandibular gland. The activity of PFK-1 expressed per gland showed no variation between diabetic and control animals. However, considering the specific activity, the soluble enzyme presented a value $50 \%$ higher than that of the control and the cytoskeleton bound form increased by $84 \%$ compared to the control. For the parotid gland, no difference in the specific activity between diabetic and control animals was observed. On the other hand, the activity per gland of the soluble enzyme increased in the diabetic animals. The phosphate content of PFK-1 increased in the submandibular and parotid glands of diabetic rats. Both the content of fructose-2,6-bisphosphate and the active form of PFK-2 were reduced in the diabetic glands. In conclusion, the increase in the activity of PFK-1 observed in the salivary glands of rats with streptozotocin-induced diabetes does not seem to be due to its modulator fructose2,6-bisphosphate.
\end{abstract}

DESCRIPTORS: Diabetes mellitus; Phosphofructokinase-1; Salivary glands; Parotid gland; Submandibular gland.

RESUMO: Apesar de existirem muitos estudos sobre a influência do diabetes nas glândulas salivares, esses apresentam resultados conflitantes. Neste estudo, a regulação da enzima fosfofrutoquinase-1 (PFK-1) foi estudada utilizando-se glândulas salivares de ratos. O diabetes foi induzido por uma única injeção intraperitonial de estreptozotocina $(60 \mathrm{mg} / \mathrm{kg}$ peso corporal) em ratos (180-200 g). Os animais foram sacrificados 30 dias após a indução do diabetes e utilizaram-se as glândulas submandibular e parótida. A hiperglicemia foi avaliada por determinação da glicemia sanguínea. A distribuição da PFK-1 entre frações solúvel e ligada, concentração de fosfato na PFK1, concentração de frutose-2,6-bisfosfato e a atividade da enzima PFK-2 foram determinadas. O cálculo do peso glandular relativo mostrou um aumento na glândula parótida de ratos diabéticos comparados ao controle, o que não ocorreu na glândula submandibular. A atividade da PFK-1 expressa por glândula não mostrou variação entre animais diabético e controle. Contudo, considerando a atividade específica, a fração solúvel da enzima mostrou aumento de $50 \%$ com relação ao controle e a fração ligada ao citoesqueleto um aumento de $84 \%$ com relação ao controle. Na glândula parótida não foi observada diferença na atividade específica entre os grupos diabético e controle. Por outro lado, a atividade por glândula da fração solúvel aumentou nos animais diabéticos. A concentração de fosfato da PFK-1 aumentou nas glândulas submandibular e parótida nos animais diabéticos. Tanto a concentração de frutose-2,6-bisfosfato quanto a forma ativa da PFK-2 mostraram redução nas glândulas salivares. Concluindo, o aumento na atividade da PFK-1 observado nas glândulas salivares de ratos com diabetes induzida por estreptozotocina não parece ser modulado pela frutose-2,6-bisfosfato.

DESCRITORES: Diabetes mellitus; Fosfofrutoquinase-1; Glândulas salivares; Glândula parótida; Glândula submandibular.

* PhDs, Professors; **Chemist - Oral Biology Research Center, School of Dentistry, University of São Paulo. 
Nicolau J, Souza DN, Nogueira FN. Activity, distribution and regulation of phosphofructokinase in salivary gland of rats with streptozotocin-induced diabetes. Braz Oral Res 2006;20(2):108-13.

\section{INTRODUCTION}

Diabetes mellitus is a metabolic disease that affects many organs and systems, including the oral cavity. Some investigations have described the effects of experimental diabetes induced either by streptozotocin or alloxan in the structure and functions of the salivary glands of animals ${ }^{2,24}$. It has been reported that diabetes decreases norepinephrine content, the density of adrenergic receptor and receptor-adenyl cyclase coupling in parotid glands ${ }^{14}$, as well as salivary secretion closely associated with the lowered susceptibility of the muscarinic receptors ${ }^{30}$. Recently it was reported that isolated parotid gland from streptozotocin-induced diabetic rats presented a dose-dependent decrease in amylase release in response to noradrenaline when compared to control parotid gland ${ }^{17}$.

The role of PFK-1 in the regulation of glycolysis has been established for a variety of cell types in various animals ${ }^{29}$. The activity of this enzyme is controlled by multiple positive and negative allosteric factors such as ATP, ADP, AMP, fructose-2,6bisphosphate (Fru-2,6- $\mathrm{P}_{2}$ ) and citrate. Fru-2,6- $\mathrm{P}_{2}$ is a potent stimulator of PFK-1 and has been detected in all mammalian tissues. The concentration of Fru-2,6- $\mathrm{P}_{2}$ is the result of a balance between the activity of PFK-2/FBP-2 as kinase and as phosphatase. Similar to other glycolytic enzymes PFK-1 may be covalently modified by phosphorylation/ dephosphorylation as a form of regulation ${ }^{18}$.

In the submandibular gland, PFK-1 was found to be synergistically regulated by ATP, fructose6-phosphate and Fru-2,6- $\mathrm{P}_{2} \cdot{ }^{28}$ In adult rat submandibular gland, Fru-2,6- $\mathrm{P}_{2}$ relieves PFK-1 from inhibition by $\mathrm{ATP}^{11}$. In previous publications ${ }^{9,21}$ we have found that PFK-1 in submandibular glands of rats treated with the $\beta$-adrenergic agonist isoproterenol has its activity and kinetics properties altered.

Considering that energy is important for the secretory functions of salivary glands, the purpose of the present investigation was to examine, in a short-term experiment, the activity, distribution and regulation of PFK-1 in the submandibular and parotid salivary glands of streptozotocin-induced diabetic rats.

\section{MATERIAL AND METHODS \\ Animals}

Thirty-two male rats of the Wistar strain weighing 180-200 g were housed individually in plastic cages with free access to water and food throughout the experimental period. The animals were randomly divided into control and diabetic groups. Diabetes was induced by a single intraperitoneal injection of streptozotocin (STZ) (Sigma-Aldrich Corporation, St. Louis, USA) dissolved in $0.01 \mathrm{~mol} /$ L citrate buffer (Sigma-Aldrich Corporation, St. Louis, USA), pH 4.5 (60 mg/Kg of body weight) in overnight fasted rats. The control animals received only the citrate buffer. The rats were killed 30 days after the induction of diabetes.

All animals were handled in accordance to the guideline of Ethical Principles in Experiments with Animals approved by the "Colégio Brasileiro de Experimentação Animal”.

\section{Tissue preparation}

The animals were killed always between 9:00 and 11:00 a.m. to minimize circadian variations. The salivary glands were immediately removed, cleaned from the adherent tissue and frozen between aluminium tongs previously cooled in dry ice and stored at $-80^{\circ} \mathrm{C}$ until analyzed.

\section{Analysis \\ Blood glucose}

It was monitored using the blood from the tail vein through the method of Somogy modified by Nelson $^{19}$ (1944). Animals were considered diabetic with blood glucose levels exceeding $19.5 \mathrm{mM}$.

\section{Determination of the soluble and cytoskeleton bound PFK-1}

The soluble and particulated PFK-1 was separated as follows: The frozen tissue was homogenized with $0.15 \mathrm{~mol} / \mathrm{L}$ sucrose solution (SigmaAldrich Corporation, St. Louis, USA) containing $1 \mathrm{~mol} / \mathrm{L}$ DTT (Sigma-Aldrich Corporation, St. Louis, USA) and $20 \mathrm{~mol} / \mathrm{L} \mathrm{NaF}$ (Sigma-Aldrich Corporation, St. Louis, USA), pH 7.5, in a glass homogenizer with a Teflon pestle. The homogenate was centrifuged at $100 \mathrm{xg}$ for 5 minutes and the sediment was discarded. The supernatant was centrifuged at $27,750 \mathrm{xg}$ for $20 \mathrm{~min}$ utes. The enzymatic activity of the supernatant of this centrifugation was considered the soluble enzyme. The enzymatic activity of the sediment was considered the cytoskeleton bound PFK-1, as described elsewhere ${ }^{23}$.

The activity of PFK-1 was assayed spectrophotometrically by monitoring the oxidation of 
Nicolau J, Souza DN, Nogueira FN. Activity, distribution and regulation of phosphofructokinase in salivary gland of rats with streptozotocin-induced diabetes. Braz Oral Res 2006;20(2):108-13.

NADH (Sigma-Aldrich Corporation, St. Louis, USA) at $340 \mathrm{~nm}$ in a system coupled to aldolase, triosephosphate isomerase and glycerophosphate dehydrogenase at two pHs: At pH 6.9, the enzyme exhibits typical allosteric kinetics and, at $\mathrm{pH} 8.2$, it presents the maximum activity in a medium (Sigma-Aldrich Corporation, St. Louis, USA) containing $50 \mathrm{~mol} / \mathrm{L}$ Hepes buffer, $10 \mathrm{~mol} / \mathrm{L} \mathrm{KCl}, 6.5 \mathrm{~mol} / \mathrm{L}$ $\mathrm{MgCl}_{2}, 1 \mathrm{~mol} / \mathrm{L} \mathrm{NH}_{4} \mathrm{Cl}, 5 \mathrm{~mol} / \mathrm{L} \mathrm{KH}_{2} \mathrm{PO}_{4}, 0.1 \mathrm{~mol} / \mathrm{L}$ AMP, $0.3 \mathrm{~mol} / \mathrm{L} \mathrm{NADH}, 0.5 \mathrm{U} / \mathrm{ml}$ aldolase, $0.5 \mathrm{U} /$ $\mathrm{ml} \mathrm{GDH}, 5 \mathrm{U} / \mathrm{ml}$ TIM, $0.1 \mathrm{~mol} / \mathrm{L}$ Fru-6-P, $0.3 \mathrm{~mol} /$ L G-6-P and $1.5 \mathrm{~mol} / \mathrm{L}$ ATP.

For the determination of the total and active (nonphosphorylated) form of PFK-2, according to the method described by Bartrons et al. ${ }^{4}$ (1983), the enzyme fructose-6-phosphotransferase purified from potato tubers ${ }^{20}$ was employed. Fructose-2,6bisphosphate was determined by the ability of this metabolite to activate the enzyme PPi: fructose6-phosphate-1-transferase purified from potato tubers ${ }^{20}$.

The phosphate content of PFK-1 purified from both salivary glands was determined based upon the methods described by Hasegawa et al. ${ }^{12}$ (1982).

Protein was estimated by the method of Lowry et al. ${ }^{15}$ (1951), using the bovine serum albumin as a standard.
Data were submitted to Student's $t$ test comparing the diabetic and control groups. Differences were accepted as statistically significant at $\mathrm{p} \leq 0.05$.

\section{RESULTS}

The diabetic animals lost weight along the experimental period. The calculated relative glandular weight (RGW) of the submandibular gland $(\mathrm{RGW}=$ glandular weight $\times 100 /$ body weight) showed no significant difference between diabetic and control rats $(0.067 \pm 0.005$ and $0.070 \pm 0.007$, respectively), while for the parotid gland the RGW was statistically higher for the diabetic group $(0.060 \pm 0.001$ and $0.030 \pm 0.007$ respectively for the diabetic and control groups).

Table 1 shows the data for the submandibular gland. Expressed as $\mathrm{mU} /$ gland no difference was observed comparing the glands from the diabetic and control animals for both soluble and particulated enzyme. However, considering the activity per $\mathrm{mg}$ of protein (specific activity) it was seen that the soluble enzyme increased by $50 \%$ and the bound, by $84 \%$ compared to the control, when the activity was determined in conditions to present allosteric properties.

For the parotid gland (Table 2) there was an increase in the activity of the soluble form of PFK-

TABLE 1 - Activity of the soluble and citoskeleton bound fractions of PFK-1 of the submandibular salivary glands of rats with streptozotocin-induced diabetes (D) and of control animals (C) determined at $\mathrm{pH} 6.9$ and at $\mathrm{pH} 8.2$.

\begin{tabular}{|c|c|c|c|c|c|}
\hline \multirow{2}{*}{ Groups } & \multirow{2}{*}{$\mathrm{pH}$} & \multicolumn{2}{|c|}{ Soluble } & \multicolumn{2}{|c|}{ Bound } \\
\hline & & $\mathrm{mU} /$ gland & $\mathrm{mU} / \mathrm{mg}$ protein & $\mathrm{mU} /$ gland & $\mathrm{mU} / \mathrm{mg}$ protein \\
\hline $\mathrm{C}(8)$ & \multirow{2}{*}{6.9} & $56.0 \pm 15.0$ & $7.6 \pm 1.9$ & $291.0 \pm 227.0$ & $30.1 \pm 9.0$ \\
\hline $\mathrm{D}(8)$ & & $59.0 \pm 12.0$ & $11.4 \pm 3.2^{*}$ & $201.0 \pm 134.0$ & $55.6 \pm 7.2^{*}$ \\
\hline $\mathrm{C}(8)$ & \multirow{2}{*}{8.2} & $124.0 \pm 15.0$ & $7.2 \pm 2.4$ & $166.0 \pm 91.0$ & $53.9 \pm 10.9$ \\
\hline $\mathrm{D}(8)$ & & $109.0 \pm 19.0$ & $6.9 \pm 1.8$ & $171.0 \pm 111.0$ & $47.5 \pm 15.6$ \\
\hline
\end{tabular}

Mean \pm SD. In parenthesis is the number of rats. The asterisk means statistically significant by Student's $t$ test comparing the diabetic and control animals $(\mathrm{p}<0.05)$.

TABLE 2 - Activity of the soluble and cytoskeleton bound fractions of PFK-1 of the parotid salivary gland of rats with streptozotocin-induced diabetes (D) and of control animals (C) determined at $\mathrm{pH} 6.9$ and at $\mathrm{pH} 8.2$.

\begin{tabular}{|c|c|c|c|c|c|}
\hline \multirow{2}{*}{ Groups } & \multirow{2}{*}{$\mathrm{pH}$} & \multicolumn{2}{|c|}{ Soluble } & \multicolumn{2}{|c|}{ Bound } \\
\hline & & $\mathrm{mU} /$ gland & $\mathrm{mU} / \mathrm{mg}$ protein & $\mathrm{mU} /$ gland & $\mathrm{mU} / \mathrm{mg}$ protein \\
\hline $\mathrm{C}(8)$ & \multirow{2}{*}{6.9} & $24.0 \pm 5.0$ & $6.4 \pm 1.6$ & $36.0 \pm 11.0$ & $18.6 \pm 5.0$ \\
\hline $\mathrm{D}(8)$ & & $33.0 \pm 6.0^{*}$ & $5.7 \pm 1.1$ & $31.0 \pm 8.0$ & $19.3 \pm 5.0$ \\
\hline $\mathrm{C}(8)$ & \multirow{2}{*}{8.2} & $156.0 \pm 51.0$ & $35.1 \pm 9.9$ & $56.0 \pm 16.0$ & $34.4 \pm 7.7$ \\
\hline $\mathrm{D}(8)$ & & $102.0 \pm 39.0 *$ & $36.4 \pm 8.2$ & $44.0 \pm 12.0$ & $28.1 \pm 8.9$ \\
\hline
\end{tabular}

Mean \pm SD. In parenthesis is the number of animals. The asterisk means statistically significant by Student's $t$ test comparing the diabetic and control animals $(\mathrm{p}<0.05)$. 
Nicolau J, Souza DN, Nogueira FN. Activity, distribution and regulation of phosphofructokinase in salivary gland of rats with streptozotocin-induced diabetes. Braz Oral Res 2006;20(2):108-13.

TABLE 3 - The activity of PFK-2 (active form and total) and the content of Fru-2,6- $\mathrm{P}_{2}$ in submandibular (SM) and parotid (P) glands of rats with streptozotocin-induced diabetes (D) and of control animals (C).

\begin{tabular}{|c|c|c|c|c|c|}
\hline \multirow{2}{*}{\multicolumn{2}{|c|}{ Groups }} & Fru-2,6- $\mathrm{P}_{2}$ & \multicolumn{3}{|c|}{ PFK-2 (pmol/g/min) } \\
\hline & & \multirow{2}{*}{$\begin{array}{l}\mathrm{pmol} / \mathrm{g} \text { tissue } \\
87.2 \pm 16.8(8)\end{array}$} & \multirow{2}{*}{$\frac{\text { Total }}{27.9 \pm 8.3(8)}$} & \multirow{2}{*}{$\begin{array}{c}\text { Active } \\
13.0 \pm 1.7(8)\end{array}$} & \multirow{2}{*}{$\frac{\text { Active/total }}{0.46}$} \\
\hline SM & $\mathrm{C}$ & & & & \\
\hline SIM & $\mathrm{D}$ & $50.2 \pm 7.6 *(8)$ & $20.0 \pm 5.5^{*}(8)$ & $7.2 \pm 1.7^{*}(8)$ & 0.36 \\
\hline \multirow{2}{*}{$\mathrm{P}$} & $\mathrm{C}$ & $172.5 \pm 22.3(8)$ & $28.2 \pm 6.4(8)$ & $19.3 \pm 5.2(8)$ & 0.68 \\
\hline & $\mathrm{D}$ & $100.6 \pm 22.3^{*}(8)$ & $18.3 \pm 2.5^{*}(8)$ & $9.0 \pm 2.4^{*}(8)$ & 0.49 \\
\hline
\end{tabular}

Mean \pm SD. In parenthesis is the number of animals. The asterisk means statistically significant by Student's $t$ test comparing the diabetic and control animals. $(\mathrm{p}<0.05)$.

1 determined at $\mathrm{pH} 6.9(37 \%)$, and a reduction at pH 8.2 (35\%) expressed per gland.

The content of Fru-2,6- $\mathrm{P}_{2}$ was reduced in the submandibular $(42.5 \%)$ and parotid glands $(41.7 \%)$ (Table 3). Similarly, the active form of PFK-2 showed reductions of about $44.6 \%$ in the submandibular and of about $53.2 \%$ in the parotid glands. The total activity also showed a reduction either in submandibular $(28.3 \%)$ or parotid $(35.1 \%)$ glands (Table 3).

The phosphate content of PFK-1 was significantly higher in the diabetic group than in the control rats for the submandibular gland (respectively 1.59 and $0.95 \mathrm{~mol} \mathrm{P} / \mathrm{mol} \mathrm{PFK}-1$ ) and for the parotid gland (respectively 1.07 and $0.74 \mathrm{~mol} \mathrm{P} / \mathrm{mol} \mathrm{PFK}-1$ ).

\section{DISCUSSION}

The results of the calculated RGW showed no variation for the submandibular gland. However, a higher value was found for the parotid gland of the diabetic animals, indicating an enlargement in comparison with the control animals, a fact that has already been reported ${ }^{3}$.

The role of PFK-1 in the regulation of metabolism is well known. The rate of the reaction catalyzed by PFK-1 is important to control the flow of glycolysis. The activity of this enzyme may be controlled by a variety of modulators as well as by phosphorylation/dephosphorylation. Our results for the submandibular gland show an increase in the specific activity of the enzyme determined at pH 6.9 for both forms, soluble (50\%) and bound to the cytoskeleton (84\%). No differences were observed either for the soluble or particulate enzyme in the activity determined at $\mathrm{pH}$ 8.2.

Contrary to the findings for the submandibular gland, the specific activity of the enzyme showed no variation for the parotid gland. However, considering the determination performed at $\mathrm{pH} 6.9$ in which the enzyme presents allosteric properties, the mean activity per gland was higher for the diabetic animals in the soluble fraction and lower than the control animals when determined at $\mathrm{pH}$ 8.2.

The diabetic rats consume more food than the control animals (hyperfagia) ${ }^{3}$. This increase in consumption may lead to an increase in the mastication and an increase in the consumption of ATP from the glycolitic pathway. PFK-1 is a key enzyme of this metabolic pathway, and the increase in activity may be a consequence of the increase in the glycolitic pathway. The differences in the results of the submandibular and parotid glands may be due to metabolic differences between the two glands. While in the SM gland the metabolism is predominantly anaerobic, the consumption of glucose may be higher than in the $\mathrm{P}$ gland, considering that its metabolism is predominantly aerobic ${ }^{22}$ and the glyclolitic pathway is more efficient. Under allosteric control, the increase in the activity observed in the SM gland shows only an increase in the activation of the PFK-1, but not an increase of the total content and the total activity of PFK- 1 in the SM gland. On the other hand, in the P gland, the lack of increase in the specific activity may have led to an increase of the RGW while, under allosteric regulations, the specific activity did not increase, but the total activity did. Without this regulation, we can not explain the decrease of the activity of PFK-1.

Many studies have shown that the induction of diabetes may lead to different results of PFK-1 activity in several tissues. Thus, for the liver ${ }^{27}$, adipocytes $^{26}$, enterocytes ${ }^{25}$, and heart atria ${ }^{8}$, reduced enzymatic activities were reported. The responses of the enzymatic activity to induced diabetes in animals were shown to be non-significant in lung ${ }^{1}$ and heart ventricle ${ }^{8}$. On the other hand, in rat peritoneal macrophage cells, PFK-1 activity was increased in cells from diabetic rats compared with those from normal rats ${ }^{7}$. 
Nicolau J, Souza DN, Nogueira FN. Activity, distribution and regulation of phosphofructokinase in salivary gland of rats with streptozotocin-induced diabetes. Braz Oral Res 2006;20(2):108-13.

To examine if the modulator Fru-2,6- $\mathrm{P}_{2}$ influenced the activity of PFK-1, we have determined the content of this metabolite and the activity of PFK-2. The steady state concentration of Fru-2,6- $\mathrm{P}_{2}$ is determined by the balance between the activity ratio of the kinase and bisphosphatase of the bifunctional enzyme (PFK-2/FBPase). In liver, Fru-2,6- $\mathrm{P}_{2}$ is described as a molecule involved in the balance between glycolytic and gluconeogenic pathways, a potent allosteric activator of the glycolytic enzyme PFK-1 and an inhibitor of the gluconeogenic enzyme Fru-1,6-bisphosphatase. Fructose-1,6-bisphosphatase is also present in the submandibular salivary glands of rats, however its activity is very low and does not vary with fasting, suggesting that the gluconeogenic process is not operating in this tissue ${ }^{22}$. Thus, in salivary glands, Fru-2,6- $\mathrm{P}_{2}$ is probably implicated only in the activation of PFK-1.

The content of the metabolite was reduced by $42.5 \%$ for the submandibular gland and by $41.7 \%$ for the parotid gland. Reductions in the concentration of Fru-2,6- $\mathrm{P}_{2}$ were also described in the atria region of the heart ${ }^{8}$, rat small intestine, enterocytes $^{25}$ and liver ${ }^{10}$ from diabetic animals. However, in macrophage cells, an increased level of this metabolite in diabetes was reported. A reduction in the mean activity of PFK-2 was observed mainly for the active (non-phosphorylated) form in submandibular $(44.5 \%)$ and in parotid glands (53.4\%). It has been pointed out that the reduced activity of PFK-1 observed in some tissues of diabetic animals was due to the reduction in the metabolite Fru-2, $6-\mathrm{P}_{2} \cdot{ }^{16} \mathrm{On}$ the other hand, in enterocytes isolated from diabetic rats, there was a significant decrease in the level of Fru-2,6- $\mathrm{P}_{2}$, but not in the activity of PFK- ${ }^{25}$. In our work both a decrease in Fru-2,6- $\mathrm{P}_{2}$ and in the activity of PFK-2 in the diabetic animals was not accompanied by a reduction in the activity of PFK-1, suggesting that the diabetic state (decrease of insulin, hyperglicemia) reduces the activity of PFK-2 and the content of Fru-2,6- $\mathrm{P}_{2}$, but not the activity of PFK-1 in salivary gland of diabetic rats. In contrast, we have found higher specific activity of PFK-1 for the submandibular gland when compared with that of the control animals, and no difference in the parotid gland between experimental and control animals. In view of these results, we

\section{REFERENCES}

1. Abuelgassim AO, Salem AM, Khoja SM. Allosteric control of 6-phosphofructo-1-kinase from rat lung. Comp Biochem Physiol B 1992;101(1-2):135-8. are led to conclude that the activation of PFK-1 in the submandibular salivary gland of diabetic rats was not due to the metabolite Fru-2,6- $\mathrm{P}_{2}$, but to another factor not known so far.

The results of the present study on the state of phosphorylation for the enzyme PFK-1 of the submandibular and parotid salivary glands of control animals are within the values reported in the literature for the liver and muscle ${ }^{6,13}$. Working with skeletal muscle from mice, Bazaes et al. ${ }^{5}$ (1982) reported higher phosphate content and about $30 \%$ lower PFK-1 activity in diabetic mice than in control animals. In the present report the values obtained for phosphate content in submandibular salivary glands from diabetic animals were higher than those of the control animals, and the specific activity was also higher than in control animals. In previous papers we have found that the specific activity of PFK-1 in the submandibular gland from rats injected with isoproterenol and killed 12 hours after the injection was higher than in control animals ${ }^{9}$, while the state of phosphorylation of the enzyme was also higher than in control animals ${ }^{23}$. Increasing the state of phosphorylation, we have found a reduction in the activity of PFK-1 in submandibular gland from rats injected with three doses of isoproterenol ${ }^{23}$.

The results of this and of previous investigations have led us to suggest that for the salivary glands, the phosphorylation of PFK-1 has dual activation. Initially, the activity of the enzyme is activated by an increased phosphorylation state. However, a higher state of phosphorylation inhibits the enzyme activity.

\section{CONCLUSION}

In conclusion, the increase in the activity of PFK-1 observed in the salivary gland of rats with streptozotocin-induced diabetes was not due to its modulator fructose-2,6-bisphosphate.

\section{ACKNOWLEDGEMENTS}

This work was supported by the "Fundação de Amparo à Pesquisa do Estado de São Paulo" (FAPESP 98/07169-9 and 99/03768-8).

2. Anderson LC. Parotid gland function in streptozotocindiabetic rats. J Dent Res 1987;66(2):425-9. 
Nicolau J, Souza DN, Nogueira FN. Activity, distribution and regulation of phosphofructokinase in salivary gland of rats with streptozotocin-induced diabetes. Braz Oral Res 2006;20(2):108-13.

3. Anderson LC, Johnson DA. Effect of alloxan diabetes on rat parotid gland and saliva. Comp Biochem Physiol B 1981;70B:725-0.

4. Bartrons R, Hue L, Van Schaftingen E, Hers HG. Hormonal control of fructose 2,6-bisphosphate concentration in isolated rat hepatocytes. Biochem J 1983;214(3):829-37.

5. Bazaes SE, Foe LG, Kemp RG. Phosphate content of muscle phosphofructokinase in the genetically diabetic mouse (C57BL/KsJ). Arch Biochem Biophys 1982;218(2):483-7.

6. Brand IA, Soling HD. Metabolite-controlled phosphorylation of phosphofructokinase in rat hepatocytes. Eur J Biochem 1982;122(1):175-81.

7. Bustos R, Moreno-Aurioles VR, Conde M, Montano R, Sobrino F. Streptozotocin-induced diabetes increases fructose 2,6-bisphosphate levels and glucose metabolism in rat macrophages. Biochem Med Metab Biol 1993;50(3):254-64.

8. Dunaway GA, Kasten TP, Naqui D. Insulin-mediated regulation of heart atrial and ventricular 6-phosphofructo-1kinase. J Biol Chem 1986;261(17):7831-3.

9. Ferreira FD, Nicolau J. Changes in glucose metabolism in submandibular salivary glands of rats after isoproterenol or incisor-tooth amputation. Arch Oral Biol 1987;32(7):499503.

10. Gil J, Carreras J, Bartrons R. Effects of diabetes on fructose 2, 6-P2, glucose 1, 6-P2 and 6-phosphofructo 2-kinase in rat liver. Biochem Biophys Res Commun 1986;136(2):498-503.

11. Hamano E, Yamazaki T, Saito M, Kawashima H, Ozeki T, Furuyama S. Comparison of phosphofructokinases in submandibular glands of immature and adult rats. Comp Biochem Physiol B 1989;94(4):697-701.

12. Hasegawa H, Parniak M, Kaufman S. Determination of the phosphate content of purified proteins. Anal Biochem 1982;120(2):360-4.

13. Hussey CR, Liddle PF, Ardron D, Kellett GL. The isolation and characterization of differentially phosphorylated fractions of phosphofructokinase from rabbit skeletal muscle. Eur J Biochem 1977;80(2):497-506.

14. Komabayashi T, Ikeda T, Suda K, Izawa T. Beta-adrenergic receptors and adenylate cyclase activity in the parotid acinar cells from acute streptozotocin-induced diabetic rats. Res Commun Mol Pathol Pharmacol 2000;107(34):311-22.

15. Lowry OH, Rosebrough NS, Farr AL, Randall RJ. Protein measurement with the folin phenol reagent. J Biol Chem 1951;193:265-75.

16. Madsen KL, Ariano D, Fedorak RN. Vanadate treatment rapidly improves glucose transport and activates 6phosphofructo-1-kinase in diabetic rat intestine. Diabetologia 1995;38(4):403-12.

17. Mahay S, Adeghate E, Lindley MZ, Rolph CE, Singh J. Streptozotocin-induced type 1 diabetes mellitus alters the morphology, secretory function and acyl lipid contents in the isolated rat parotid salivary gland. Mol Cell Biochem 2004;261(1-2):175-81.

18. Mahrenholz AM, Lan L, Mansour TE. Phosphorylation of heart phosphofructokinase by $\mathrm{Ca}^{2+} /$ calmodulin protein kinase. Biochem Biophys Res Commun 1991;174(3):12559.

19. Nelson N. Photometric adaptation of the Somogyi method for the determination of glucose. J Biol Chem 1944;153:375-8.

20. Nicolau J, de Souza DN, Martins HR. Pilocarpine-induced increases in the activity of 6-phosphofructo-2-kinase and the fructose-2,6-bisphosphate content of rat salivary glands. Arch Oral Biol 1992;37(6):483-7.

21. Nicolau J, Nunez-Burgos GB. Phosphofructokinase-1 in the nuclear and cytoplasmic fraction of the submandibular salivary glands from isoproterenol-treated rats: $\mathrm{Km}$ and isoenzymes. Med Sci Res 1991;19:381-3.

22. Nicolau J, Sassaki KT. Metabolism of carbohydrate in the major salivary glands of rats. Arch Oral Biol 1976;21(11):659-61.

23. Nicolau J, Souza DN, Nunez-Burgos G. Regulation of phosphofructokinase- 1 on submandibular salivary glands of rats after isoproterenol administration. Arch Physiol Biochem 2000;108(5):437-43.

24. Reuterving CO, Hagg E, Henriksson R, Holm J. Salivary glands in long-term alloxan-diabetic rats. A quantitative light and electron-microscopic study. Acta Pathol Microbiol Immunol Scand [A] 1987;95(3):131-6.

25. Rossi I, Sanchez-Arias JA, Feliu JE. Effect of streptozotocin diabetes on the glycolytic flux and on fructose 2,6bisphosphate levels in isolated rat enterocytes. Metabolism 1990;39(8):882-5.

26. Sobrino F, Saggerson ED. Measurements of glycolytic flux rate in brown adipocytes. Effects of insulin, noradrenaline and streptozotocin diabetes. Biochem Int 1989;19(2):325-32.

27. Sochor M, Baquer NZ, Ball MR, McLean P. Regulation of enzymes of glucose metabolism and lipogenesis in diabetic rat liver by thyroid hormones. Biochem Int 1987;15(3):619-27.

28. Sugiya H, Fujita Y, Fukushima E, Yamazaki T, Furuyama S. Fructose 2,6-bisphosphate-dependent regulation of phosphofructokinase in rat submandibular gland. Int J Biochem 1988;20(3):237-41.

29. Uyeda K. Phosphofructokinase. Adv Enzymol Relat Areas Mol Biol 1979;48:193-244.

30. Watanabe M, Yamagishi-Wang H, Kawaguchi M. Lowered susceptibility of muscarinic receptor involved in salivary secretion of streptozotocin-induced diabetic rats. Jpn J Pharmacol 2001;87(2):117-24. 